\title{
INTRODUCCIÓN
}

\section{LA TEORÍA NO SE OPONE A LA PRAXIS}

\author{
Por: Santiago Castellanos, Ph.D. \\ Decano COCOA
}

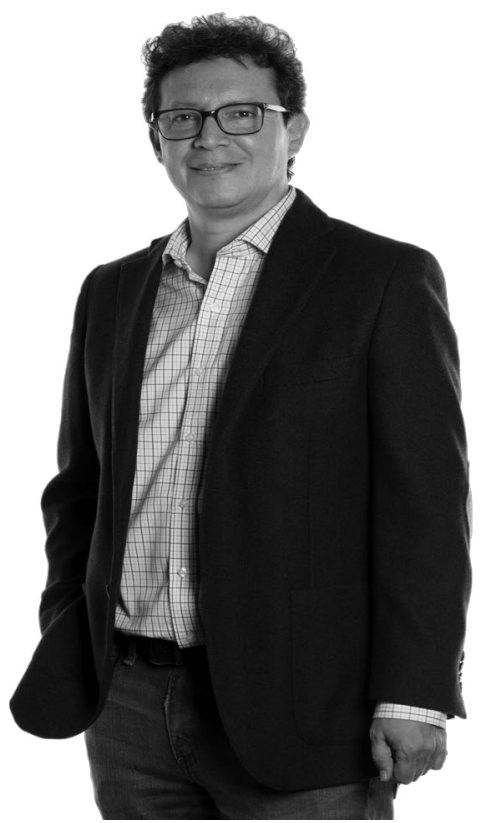

$\mathrm{P}$

lasmar en una publicación como esta experiencias y debates en torno al periodismo tiende a revivir esa vieja y ya conocida dicotomía entre los académicos y los profesionales, es decir, ese falso binario entre teoría y praxis: nosotros los periodistas versus ustedes los académicos, o el «hacer» versus el «pensar» (Burgos, 2015).

A veces, podría parecer productivo mantener estas dicotomías. Por ejemplo, podrían parecer pertinentes cuando las demandas de la praxis académica convencional devienen en ejercicios de teoría por la teoría y se cree necesario inyectarla de experiencias de vida o testimonios. O viceversa, podrían parecer útiles cuando la praxis profesional parece desligada de los cambios culturales y sociales, y se cree necesario inyectarla de teoría. 
Esta serie monográfica es una invitación a problematizar, de una vez por todas, esas dicotomías, que por cierto ya han sido problematizadas desde hace como treinta años. Desde el COCOA, abrimos este y otros espacios de cuestionamiento a periodistas y académicos del periodismo del Ecuador y el mundo.

Dentro de estas discusiones, ¿cuáles son los presupuestos sobre el ser, el conocer, el hacer, o el deber ser de, por ejemplo, las mallas académicas de nuestras escuelas de periodismo? ¿Qué prespuestos subyacen a las prácticas profesionales en medios de comunicación? ¿Cuáles son nuestras definiciones operativas de lector, audiencia, cliente, usuario, consumidor, prosumidor o procomún en este mundo digital neomediático interactivo?

¿Existen estas nuevas tecnologías dentro de dinámicas de poder ya establecidas y fijas o, por el contrario, tienen estas nuevas tecnologías agencia y capacidad de efectuar transformaciones económicas, sociales y culturales? ¿Determinismo tecnológico, o determinismo social o económico? ¿Qué sucede con el periodismo cuando los productos periodísticos que emergen en estas nuevas realidades tecnológicas requieren dediseñadores, productores de audiovisuales, animadores, artistas, publicistas, guionistas (dramaturgos), comunicadores, expertos en interactividad, estadísticos y matemáticos, además de periodistas?

Como dice Judith Butler, "toda definición es una forma abreviada de teoría” (2015). Las definiciones que utilizamos, consciente o inconscientemente, están saturadas de presupuestos teóricos que no siempre elegimos, que nos preceden, pero que delimitan lo que somos y lo que hacemos. Algunos de ellos están tan naturalizados (son como el aire que respiramos) y, aunque operan casi automáticamente - performativamente, como diría Butler - son localizables en un tiempo y un espacio determinados y, por tanto, susceptibles de cambio y transformación.

Pero otro ejemplo de esta necesidad imperiosa de reflexionar sobre la práctica del periodismo, en términos que no sitúen a la praxis como "lo útil" y a la teoría como una "abstracción inútil", procede de las controversias que emergieron, y siguen emergiendo, a partir de sucesos dolorosamente recientes de Francia, Líbano, Kenia, y Siria. Butler nos invita a considerar seriamente cuáles son los marcos de inteligibilidad que hacen que las muertes de ciertos seres humanos sean más dignas de ser lloradas que las muertes de otros seres humanos (2009).

El periodismo, a menudo, se encuentra en el centro de debates teóricos trascendentales, como el significado de la libertad, la democracia, o la misma condición humana, por nombrar solo algunos.

Pero la misma práctica profesional es en sí misma un ejercicio de teoría. Nuestros productos periodísticos son definiciones, es decir, teorías abreviadas de los hechos, personas o grupos que estamos representando. 


\section{Cambios paradigmáticos}

Aunque es ya casi un cliché hablar de cambios paradigmáticos en cualquier discusión académica, parece serque el momento comunicacionaly político en el que vivimos a nivel mundial nos demuestra que no estamos del todo preparados para las transformaciones sociales y culturales que se nos vienen encima. Eso lo demuestran muchos de los sorprendentes resultados electorales recientes.

De acuerdo con Blumler \& Coleman (2015), estos cambios paradigmáticos exigen reflexiones profundas sobre el significado de ciertos aspectos claves en el ejercicio de la comunicación y el periodismo.

Uno de ellos tiene que ver con el significado de la comunicación y la acción cívica. Por ejemplo: ¿Sirven los medios a propósitos de vigilancia ciudadana? ¿Con qué frecuencia ofrecen oportunidades de escuchar voces marginalizadas? ¿Ayudan a procesos de rendición de cuentas de personas en posiciones de ejercicio de poder? ¿Abren líneas de diálogo entre los ciudadanos y las personas en posición de tomar decisiones? ¿Ayudan a que los lectores establezcan interrelaciones entre sucesos y entiendan la complejidad de las situaciones?

Otro aspecto importante es el eje medios-política. ¿Qué sucede con los debates relativos a las oportunidades y peligros de la llamada "mediatización de la política”? ¿Cuál es nuestra posición, tanto ética como crítica, en situaciones en las que la lógica mediática parece tener precedencia por sobre la lógica política?

¿Qué sucede con los contradictorios y complejos efectos de los nuevos medios? Aquí entran esasparadojasque emergendelasupuestaabundancia demediosydeinformación frente a la persistencia de ciertas voces dominantes, o a los procesos de autoselección de información, típicos de la era digital, y que hace que como usuarios terminemos consumiendo única y exclusivamente aquella información que de antemano queríamos escuchar.

Y tal vez el más relevante aspecto mencionado por Blumler y Coleman tiene que ver con el significado mismo de la democracia, concepto de por sí cambiante y siempre en disputa. ¿Qué significados adquiere el concepto de democracia en la era de los nuevos medios? ¿Qué significa democracia en la era de la mediatización de la política? ¿Qué significa democracia para los millennials? ¿Cómo enfrentamos la discrepancia entre los ideales democráticos y lo que se logra en realidad? ¿O qué hacer con el desencanto electoral, con ese sentimientode frustración, cinismo, desconfianza, ofalta de compromiso que surge de lo poco que sentimos que obtenemos del ejercicio democrático, independientemente de que pierda o gane el candidato o partido de nuestra elección?

En su libro How Voters Feel, Stephen Coleman (2013) argumenta a favor de la necesidad de hacer una exploración cualitativa que indague precisamente en aquellos aspectos 
emocionales que siempre están presentes en el ejercicio político, pero que han sido menospreciados debido al énfasis en la racionalidad, lo observable, en los datos medibles y cuantificables.

El giro epistemológico hacia lo afectivo y hacia los sentimientos que propone Coleman resuena con incursiones en las emociones que desde hace ya un par de décadas estaban presentes en los estudios culturales, las teorías de género y los feminismos, los estudios sobre el colonialismos y los estudios sobre diversidades sexuales y teorías queer. Sara Ahmed (2015), en un libro maravilloso e innovador titulado La Política Cultural de las Emociones, nos pide considerar las implicaciones políticas de los afectos: en otras palabras, Ahmed nos invita a reflexionar sobre el rol que desempeñan emociones como el dolor, el odio, el miedo, el asco, la vergüenza o el amor en el juego político.

Recordemos que la creación de comunidades y de otredades está marcada por aspectos emocionales. Las palabras, el lenguaje, las imágenes y los signos tienen cargas afectivas con efectos performativos, es decir producen políticas colectivas, alianzas sociales, o formas de identificación y acción política.

En \#PerDebate, abrimos la discusión para todas estas preguntas, para todos esos temas que nos interesan, que nos apasionan, que nos desafian, o que nos sorprenden. Y también para todos aquellos aspectos para los cuáles aún no tenemos respuesta pues ese es el reto de construir conocimiento desde la academia, en una combinación de experiencia profesional periodística, investigación y análisis del cambio y otros cambios paradigmáticos.

\section{Referencias}

Burgos, H. (2015). Un encuentro de post(s). ¿Es posible disociar el hacer del pensar? $¿$ Es posible disociar el pensar del hacer? post(s) 1, 9-30.

Blumler, J.G., y Coleman, S. (2015). Democracy and the Media-Revisited. $22,2,111-128$.

Butler, J. (2015). Keynote Adress. Conferencia Desfazendo Género, Salvador de Bahía, Brasil. Septiembre 6, 2015.

Butler J. (2009). Marcos de guerra: Las vidas lloradas. Buenos Aires, Planeta.Blumler, J.G. y Coleman, S. (2015). Democracy and the media: Revisited. Favnost: The Public, 22, 2, 111-128.

Coleman, S. (2013).How Voters Feel. Cambridge, Cambridge University Press.

Ahmed, S. (2015). La politica cultural de las emociones. México, Programa Universitario de Estudios de Género de la UNAM. 